\title{
HANDBOOK OF SUPERSONIC AERODYNAMICS
}

\author{
SECTION 7 \\ THREE-DIMENSIONAL AIRFOILS
}

PRODUCED AND EDITED BY THE AERODYNAMICS HANDBOOK STAFF OF THE JOHNS HOPKINS UNIVERSITY. APPLIED PHYSICS LABORATORY, SILVER SPRING, MARYLAND. UNDER CONTRACT NORD 7386 WITH THE BUREAU OF ORDNANCE, DEPARTMENT OF THE NAVY. THE TEXT OF THIS SECTION WAS PREPARED LARGELY BY R. M. PINKERTON. THE SELECTION AND TECHNICAL REVIEW OF THIS MATERIAL WERE FUNCTIONS OF A REVIEWING COMMITTEE OF THE LABORATORY CONSISTING OF IONE D. V. FARO, LESTER L. CRONVICH, AND ROBERT N. SCHWARTZ (CHAIRMAN).

For sale by the Superintendent of Documents, U. S. Government Printing Office

Washington 25, D. C. - Price $\$ 1.50$

\section{AUGUST 1957}

